\title{
Globalisation as a motor of renewable energy development in Latin America countries
}

\author{
Matheus Koengkan ${ }^{1}$, Yormy Eliana Poveda ${ }^{2}$, and José Alberto Fuinhas ${ }^{3, *}$ \\ ${ }^{1}$ CEFAGE-UE and Department of Economics, University of Évora, Portugal \\ ${ }^{2}$ Department of Economics, Federal Fluminense University, Brazil \\ ${ }^{3}$ NECE-UBI, CeBER, and Faculty of Economics, University of Coimbra, Portugal
}

\begin{abstract}
The impact of globalisation on the dissemination of renewable energy was analysed for ten Latin America countries for the period from 1980 to 2014. For that propose, was built a model where install capacity of renewable energy is explained by output, KOF globalisation index, and private capital stock. The richness of the short- and long-run relations between variables was analysed by a panel autoregressive-distributed lag model in the form of an unrestricted error correction mechanism. The results of the model's estimation support a positive effect of the short-run impact of output per capita and long-run elasticities of globalisation and private capital stock per capita on renewable energy diffusion. That results that show that the globalisation can stimulate renewable energy sources evidencing that the process of integration of Latin America countries in the World is a benefit to the development of green energy technologies. The Latin America region policymakers must take advantage of the process of globalisation to reduce the costs of renewable energy technologies and develop policies encouraging the access of these technologies by households with low income that live in remote or rural regions to reduce the energy poverty, which plagues the countries from the Latin America region.
\end{abstract}

Keywords: Globalisation; renewable energy; private capital stock; Latin America countries; panel ARDL.

\section{Introduction}

Latin America countries have experienced growth in the use of renewable energy for electricity generation (Washburn \& Pablo-Romero, 2019). In that process, globalisation has facilitated the access to technological advances contributing to the increase of the renewable energy capacity in Latin America countries. Indeed, the globalisation, through its stimulus of trade and quality of investment, has contributed to the technological change in the energy industry in the Latin America region.

Even though Latin America countries have expanded the production of fossil energies, the renewable energy capacity has increased more, what explain the superior level of renewables when comparing with other World's regions (Washburn \& Pablo-Romero, 2019). Indeed, the renewable energy in Latin America countries has a high share (about 28\%) in the total energy consumption, what represents a larger share than the $18.3 \%$, on average, of the World (Washburn \& Pablo-Romero, 2019). Renewable energy is vital too in electricity generation, where hydroelectric is the most representative (90\%) in Latin America countries. However, the hydroelectric participation between 2006 and 2015 decreased (Washburn \& Pablo-Romero,

\footnotetext{
* Corresponding Author: matheuskoen@hotmail.com.br; Department of Economics, University of Évora, Colégio do Espírito Santo, Largo dos Colegiais, 2, 7000-803 Évora, Portugal.

Centre for Business and Economics Research - CeBER.

Research supported by: NECE, R\&D unit funded by the FCT - Portuguese Foundation for the Development of Science and Technology, Ministry of Science, Technology and Higher Education, project UID/GES/04630/2019.
} 
2019). A possible explication for that falling is the increasing of wind and photovoltaic energy in the Latin America region.

According to ECLAC (Griffith-Jones et al., 2017), one of the driving forces to increase the investment in renewables energy in recent years has been the significant reduction in their costs, compared to fossil fuel power generation. The renewable energy generation technologies had been available at lower costs. Thanks to economic integration, Latin America countries have access to energy technologies and adopted them in their industry. With the greater economic integration, the technology transfer to renewable energy depends on the production and absorption capacity and the path dependency of significant investments in technologies.

Globalisation has reduced the problem of financing the costs of the project for renewables energy. For example, there is a continual decline in the cost of electricity from renewable-based technologies, due to the lower power generation equipment costs, as the increasingly efficient technologies (Griffith-Jones et al., 2017).

Even if the globalisation has been a determinant element in renewable energy, the energy policy has oriented the development and utilisation of renewable energy through incentives. Also, the external financing of renewable projects has been a driving force to increase the installed capacity in the Latin America countries, except for Bolivia and Venezuela (Washburn \& PabloRomero, 2019). Although the incentives have been the most common instrument for renewable energy in Latin America countries, it is not clear what kind of systematical incentives must adopt to attain appropriate levels of technology diffusion (Zuluaga \& Dyner, 2007). So, is necessarily highlighting that globalisation and technology diffusion must have an advantage through opportunism strategies for increasing renewable energy. Globalisation per se is not a driving force for renewable energy, but it has facilized the technology diffusion through the direct incentives for renewable energy at lower costs.

Hence, our study finally offers the following findings. First, economic growth has a positive effect on the investments in installed capacity for renewable energy. An explanation is associated with the potential of renewable energy resources in the Latin America countries, that stimulate the investments of alternative energy sources. Second, the capital stock has a positive impact on the investments in the installed capacity of energy. That is due to cheaper capital, which stimulates the investments. Finally, the positive effect of globalisation is an incentive to the economic growth and consequently increase the energy demand and investments in renewable technologies in order to attain the demand level required.

This investigation is innovative and adds to the literature in various ways: (i) it is the first assessment of the impact of globalisation on the installed capacity of renewable energy, i.e. aiming at explaining the investments diffusion of this kind of source; (ii) it considers globalisation and private capital stock as independent variables with the purpose of explain the increase of the installed renewable capacity; (iii) it uses the PARDL in the form of a UECM; and (iv) it focuses on Latin America, investigating a group of countries that was not previously considered in the literature. Indeed, previous assessments have been focused solely on studying countries in Asia, the Middle East, and Europe. Latin America is of interest not only because it was not studied before, but also because of its social, political, and economic specificities that may help to explain the relationships under research in this investigation. Beyond its academic interest, our empirical analysis is also useful for Latin American policymakers, as it may help in the design of effective policies aimed at promoting the development of renewable energy technologies.

The paper is structured as follows. In Section 2, we discuss the literature, and in Section 3 is shown the methodology. In Section 4 are revealed the empirical results and a discussion about that. Finally, Section 5 ends up with final remarks. 


\section{A brief debate of the effect of globalisation on renewable energy}

Prior literature has focused on understanding the effect of globalisation at the national level or in a selected industry, but not addressed the issue of how globalisation impacts the performance of renewable energy capacity. The globalisation literature includes a diversity of sub-topics such as economics, politics, culture, social relations, technology, and migration (Overland, 2016), but renewable energy is lacking studies.

The conclusion about the missing link between renewable energy or energy and globalisation is not recently. Sovacool (2014), with a seminal work, studied the state of research in energy studies and recognised the lack of literature about that relationship. The literature on energy and globalisation is vast, but hardly any touch on both energy and globalisation (Overland, 2016).

One of the approximations between globalisation and energy is related to studies focused on the trade of energy resources, the exploring, transforming and exploiting energy. Authors as Overland (2016) examined the globalisation of coal, natural gas, nuclear fuel, and oil and oil products, through the construction on a compound index. He suggested a gradual growth of the energy globalisation. Now, about renewable energy, Overland (2015) explained that energy globalisation would abate if a renewable or nuclear energy technology revolution takes place.

In general, the literature about globalisation often shows that this phenomenon has significant effects on the increase in trade and investment. By one hand, between 1981 and 2018 world trade growth, as a ratio to world gross domestic product (GDP), increased from around $0.1 \%$ to above $1.4 \%$ (World Trade Organisation, 2019). By another hand, the Foreign Direct Investment (FDI) is a visible effect of globalisation too. FDI is a form for investors acquires foreign business assets or establishes foreign business operations. In developing economies, FDI has been an essential source of external finance over the past decade (United Nations, 2018).

The literature linking the trade and investment, as a direct result of globalisation, appoint some specificities that need understanding (Storper, 2000). The critical agents in global trade and investment are the Multinational enterprises (MNEs). Specifically, MNEs are essential to the intangible knowledge resources in many of the large-scale mass production industries (Storper, 2000). There is a relation between globalisation and technological change, as it has the following impact on the industrial sector and the global economy (Miozzo et al., 2005; Jones, 1998).

The specific effects for developed and less developed countries in the period of globalisation is different but interrelated. By one hand, for emerging economies as Brazil, Singapore and China, the globalisation allowed a competitive pressure and the more accessible access to technological progress (Vu, 2018; Pangawar and Wu, 2012; Miozzo et al., 2005; Amann, 2002). Less developed countries can appropriate technologies according to the availability of resources. It means that the technology development paths depending on the capacity to absorb innovations. In the other hand, developed countries are technology leadership, with the capacity to research and developing new products and process (Miozzo et al., 2005). In this sense, the leadership, through mergers and acquisitions, can transfer technology to less developed countries (Lacal-Arántegui, 2019).

Globalisation is an opportunity to increase technology transfers. As Jones (1998) argued, globalisation will lead to higher rates of technology development and diffusion. The costs of new technologies will be reduced, and it will be possible the use of environmentally friendly technologies for all the countries (Jones, 1998). Also, Lacal-Arántegui (2019) argued the existence of a relationship between globalisation, innovation and trade. The globalisation is a driving force to construct new technology and improvement in the wind energy industry, which affects the European companies manufacturing turbines and developing wind farms. 
Literature about renewable energy recognises innovation as a core element to lead the substitution of fossil energy sources by renewable sources within firms (Gielen et al., 2019; Horbach \& Rammer, 2018). The falling costs and competitiveness is leading the increasing of installed renewable energy power capacity (Gielen et al., 2019).

At last, there is a literature point out that renewable energy has positive impacts on employment and economic growth (Gielen et al., 2019; Lacal-Arántegui, 2019). Lacal-Arántegui highlighted that the European wind industry had attracted jobs and growth for Europe thanks to the globalisation. The process of increasing renewable energy capacity was demanding additional direct and indirect jobs in other sectors of the economy to construction, maintenance, and functioning of the energy infrastructure.

In short, globalisation had given the advantage to satisfy the demand of energy renewable as specialised services to install the technologies and goods. Also, and more importantly, globalisation makes it easier to integrate the technologies into the firm's existing energy supply and production systems.

According to previous literature, none are an analysis of the renewable energy industry and globalisation. Then, we believe that our paper extends the previous literature, conceptually studying the energy globalisation as well empirically, using PARDL model to study the missing link between renewables energy and globalisation.

\section{Methodology and database}

This section is organised into two sub-sections, where the first will evidence the methodology, while the second approach the variables that will be used.

\subsection{Methodology}

In order to the realisation of this investigation, we opted to use the PARDL model in the form of a UECM, a methodology developed by Granger (1981) and Engle and Granger (1987) and subsequently improved by Johansen and Juselius (1990) with the introduction of cointegration practices. This technique has a propose of decomposing the total effects of the variables into their short-and long-run components (e.g. Koengkan et al., 2019a; Koengkan et al., 2019b).

The use of this methodology has some advantages which include: (i) the possibility to deal with the presence of cointegration among the variables; (ii) allows to includes in the model without any difficulty, variables which are I(0) and I(1); (iii) can produce efficient parameter estimates with relatively small samples; and (iv) can produce robust estimates in the existence of endogeneity among the variables.

Additionally, this technique is more flexible than other methodologies, such as the Dynamic OLS (DOLS), Fully Modified OLS (FMOLS), and Generalized Method of Moments (GMM) (e.g. Koengkan et al., 2019). So, for all these reasons, we selected that methodology to carry out this investigation. The general PARDL model follows the specification of Eq. (1):

$$
\begin{aligned}
& \text { DLnIREC } i t=\alpha_{i}+\beta_{1 i 1} D \operatorname{LnGDP} P_{i t}+\gamma_{1 i 1} \operatorname{LnIREC}_{i t-1}+\gamma_{1 i 2} \operatorname{LnGLOBA}_{i t-1}+ \\
& \gamma_{1 i 3} \operatorname{LnKPRIV} i t-1+\varepsilon_{1 i t} \text {. }
\end{aligned}
$$

where the $\alpha_{i}$ represents the intercept, $\beta_{i k}$ and $\gamma_{i k}$, with $\mathrm{k}=1, \ldots, 3$, denote the estimated parameters, while $\varepsilon_{i t}$ represents the error term. The prefixes "Ln" and "DLn" denote natural logarithms and first differences.

The best econometric practices strongly recommend which before the realisation of ARDL estimation, it is necessary to understand the characteristics of cross-sections and series, 
also, to verifying the existence of singularities which it is not taken into account, and which could lead to inconsistent and incorrect interpretations. In order to avoid these mistakes, some preliminary and specification tests will be computed in this investigation. Indeed, the preliminary and specification tests which will be carried out are: (i) Preliminary tests: (a) Variance Inflation Factor (VIF); (b) Cross-sectional Dependence (CSD-test) (Pesaran, 2004); (c) $2^{\text {nd }}$ generation unit root test (CIPS-test) (Pesaran, 2007); (d) Hausman test to verify the presence of heterogeneity, i.e. whether the panel has random effects (RE) or fixed effects (FE); and (e) Mean Group (MG), and Pooled Mean Group (PMG) estimators; (ii) Specification tests: (a) Modified Wald test (Greene, 2002); (b) Wooldridge test (Wooldridge, 2002); (c) Friedman test (Friedman, 1937), and (d) Breusch and Pagan Lagrangian multiplier test (Breusch and Pagan, 1980). To performing the econometric equations of this investigation, the software Stata 15.0 will be used. In the next section will show the data that will be used.

\subsection{Database}

To study the influence of globalisation on the installed capacity of renewable energy, ten countries from Latin America region were selected, for example, Argentina, Bolivia, Brazil, Chile, Colombia, Ecuador, Mexico, Nicaragua, Peru, and Uruguay in a period ranging from 1980 to 2014. Indeed, this group of countries was selected for a reason that: (i) they have experimented a rapid process of globalisation that started in the 1970s; (ii) they have registered a rapid growth in the installed capacity of renewable energy; and (iii) they have experimented a rapid economic growth in the last thirty-four years. Additionally, the period was chosen due to the availability of data for all countries of this investigation and also due to the PARDL model requires that the panel data be strongly balanced (Koengkan et al., 2019b).

The data/variables used in this investigation included: (a) dependent variable, such as (i) Install capacity of Renewable energy in (Million Kilowatts) (IREC), available from the International Energy Administration (IEA, 2018); (b) independent variables, such as (i) Gross Domestic Production (GDP) in constant local currency units (LCU), available from the World Bank Data (WDB, 2018); (ii) Globalization index (GLOBA), available from the KOF Globalisation index (KOF, 2018). This variable measures the economic, social, and political dimensions of globalisation on a scale from 1 to 100. Moreover, due to the presence of some zeros in the index, the research was performed transforming the raw globalisation index by adding 1 to the index; and (iii) Private capital stock (KPRIV) (constructed based on private investment flows), in billions of constant 2011 international dollars, available from the Investment and Capital Stock Dataset" released by the International Monetary Fund (IMF, 2017).

The variables (IREC, GDP, and KPRIV), were transformed into per capita values. Indeed, the use of per capita values let us control the disparities in the population growth over time and among the countries of investigation (e.g. Koengkan, 2019a; Fuinhas et al., 2017). Additionally, the use of constant GDP in local currency units (LCU), as an alternative of constant international US dollars reduces the effect of both the inflation and deviation of exchange rates (e.g., Koengkan, 2018a; Koengkan, 2018b). Table 1 shows the variables description and summary statistics.

Table 1. Descriptive statistics of variables

\begin{tabular}{lccccc}
\hline \multirow{2}{*}{ Variables } & \multicolumn{5}{c}{ Descriptive statistics } \\
\cline { 2 - 5 } & Obs. & Mean & Std.-dev. & Min. & Max. \\
\hline LnIREC & 350 & 2.4854 & 1.6384 & -1.0526 & 6.1291 \\
LnGDP & 350 & 10.7417 & 2.6517 & 7.6628 & 16.1937 \\
LnGLOBA & 350 & 3.9428 & 0.2077 & 3.4706 & 4.3215 \\
LnKPRIV & 350 & -11.5113 & 0.5862 & -12.6475 & -10.5307
\end{tabular}

Notes: (Ln) denotes variables in the natural logarithms; Obs. denotes the number of observations in the model; Std.dev. denotes the Standard Deviation; Min. and Max. denote Minimum and Maximum; the command sum of Stata was used. 
This section showed, the methodology which approaches the preliminary and specification tests that will be applied to achieve the aim of this investigations and data/variables which will be used. The next section will show the empirical results of this investigation.

\section{Results and discussion}

This section will evidence the outcomes of preliminary and specification tests and the estimated model. In order to understand the degree of multicollinearity, as well as to detect the presence of cross-section dependence among the variables, the first step is to compute the VIF and CSD-tests. The null hypothesis of CSD-test is the existence of cross-sectional dependence in the variables. Table 2 shows the outcomes of VIF and CSD-tests.

Table 2. Variance inflation factor (VIF) and cross-sectional dependence (CSD) check

\begin{tabular}{|c|c|c|c|c|c|c|}
\hline Variables & VIF & $1 / \mathrm{VIF}$ & CD-test & $\mathrm{p}$-value & Corr & Abs (corr) \\
\hline LnIREC & \multicolumn{2}{|c|}{ n.a. } & 29.17 & 0.000 & 0.735 & 0.735 \\
\hline LnGDP & 1.08 & 0.9224 & 30.95 & 0.000 & 0.780 & 0.780 \\
\hline LnGLOBA & 1.29 & 0.7764 & 36.76 & 0.000 & 0.926 & 0.926 \\
\hline LnKPRIV & 1.21 & 0.8260 & 7.87 & 0.000 & 0.198 & 0.478 \\
\hline Mean VIF & \multicolumn{2}{|c|}{1.19} & & & & \\
\hline DLnIREC & \multicolumn{2}{|c|}{ n.a. } & -0.28 & 0.780 & -0.007 & 0.191 \\
\hline DLnGDP & 1.02 & 0.9851 & 13.39 & 0.000 & 0.342 & 0.344 \\
\hline DLnGLOBA & 1.00 & 0.9990 & 8.50 & 0.000 & 0.217 & 0.244 \\
\hline DLnKPPC & 1.01 & 0.9860 & 12.16 & 0.000 & 0.311 & 0.355 \\
\hline Mean VIF & \multicolumn{2}{|c|}{1.01} & & & & \\
\hline
\end{tabular}

The results of low and mean VIF values indicate that the variables in the natural logarithms and first-differences are lower than the usually accepted benchmarks of 10 , and in the case of mean VIF values is lower than 6.

However, in the presence of CSD, it is recommended to check the order of integration of the variables. To this end, the unit root test of second-generation, which is robust in the presence of CSD, was computed. The null hypothesis rejection is that the variable is I(1). The results of this test can be seen in Table 3 .

Table 3. Unit root test.

\begin{tabular}{l|ccccc}
\hline \multirow{2}{*}{\multicolumn{1}{c|}{ Variables }} & \multicolumn{4}{|c}{$2^{\text {nd }}$ generation unit root test } \\
\cline { 2 - 5 } & \multicolumn{4}{|c}{ Pesaran (2007) panel unit root test (CIPS) (Zt-bar) } \\
\cline { 2 - 5 } & \multicolumn{4}{c}{ Without trend } \\
\cline { 2 - 5 } & Lags & Zt-bar & p-value & Zt-bar & p-value \\
\hline LnIREC & 1 & -2.725 & 0.003 & -2.815 & 0.002 \\
LnGDP & 1 & -1.234 & 0.109 & -1.224 & 0.111 \\
LnGLOBA & 1 & -3.366 & 0.000 & -1.605 & 0.054 \\
LnKPRIV & 1 & 1.778 & 0.962 & -0.030 & 0.488 \\
\hline DLnIREC & 1 & -10.360 & 0.000 & -9.084 & 0.000 \\
DLnGDP & 1 & -5.418 & 0.000 & -4.887 & 0.000 \\
DLnGLOBA & 1 & -7.095 & 0.000 & -5.480 & 0.000 \\
DLnKPRIV & 1 & -1.953 & 0.025 & 0.205 & 0.581 \\
\hline
\end{tabular}

Notes:(Ln and DLn) denote variables in natural logarithms and first-differences of logarithms respectively The Stata command pescadf was used; the null for CIPS test is: series are I(1); the lag length (1) and trend were used in this test.

The CIPS-test was used with lag length (1) without trend and with the trend. The results of this test indicated that none of the variables seems to be $\mathrm{I}(2)$, as well as some of them, are in the borderline between the $\mathrm{I}(0)$ and $\mathrm{I}(1)$ order of integration. 
After the realisation of the unit root test, it is recommended to verify the existence of individual effects. For this end, the Hausman test, which confronting the random (RE) and fixed effects (FE), was used. The null hypothesis of this test is that the best estimator is the RE.

The results of the Hausman test indicate that the FE estimator is the most suitable for this analysis, where the (Chi2 $(4)=77.72$ with p-value $<0.000)$ which is statistically significant at $1 \%$ levels. In order to verify the existence of heterogeneity or homogeneity in the panel, the mean group (MG), pooled mean group (PMG), and fixed effects (FE) were confronted. The FE and MG estimators that were developed by Pesaran and Smith (1995) calculate an average coefficient for all individuals, without restrictions regarding the homogeneity of the long-run coefficients.

The PMG that also was developed by Pesaran et al., (1999) allows differences in the error variances, short-run coefficients, the speed of adjustment, and also intercept, but it imposes the homogeneity restriction on the long-run coefficients. This estimator can combine the "pooling" from the FE estimator with the "averaging" from the MG estimator. Moreover, the PMG estimator in the presence of homogeneity is more efficient than the MG in the long-run. Table 4 shows the outcomes from the Hausman tests between the following specifications (e.g., MG vs PMG; PMG vs FE, and MG vs FE).

Table 4. Hausman test

\begin{tabular}{ccc}
\hline MG $v s$ PMG & PMG vs FE & MG vs FE \\
\hline Chi2(5)=1.97 & Chi2(5)=-1.00 & Chi2(5)=149.75** \\
\hline
\end{tabular}

Notes: $* * *$ denotes statistically significant at $1 \%$; Hausman results for $\mathrm{H}_{0}$ : difference in coefficients not systematic; the Stata commands xtpmg, and Hausman (with the options, alleqs constant) were used.

The outcomes from the Hausman test indicate that the FE estimator is the most appropriate and that the panel is homogenous. Well, before the realisation of ARDL estimation, a battery of specification tests needs to be applied. To this end, some specification tests were computed, for example: (i) Modified Wald test; (ii) Wooldridge test; (iii) Friedman test; and (iv) Breusch and Pagan Lagrangian multiplier test. Table 5 shows the outcomes of specification tests.

Table 5. Specification tests

\begin{tabular}{llccc}
\hline \multirow{2}{*}{ Statistics } & \multicolumn{1}{c}{ Modified Wald test } & Wooldridge test & $\begin{array}{c}\text { Friedman's } \\
\text { test }\end{array}$ & Breusch and Pagan LM test \\
\cline { 2 - 4 } & $\begin{array}{l}\text { chi2 }(10)= \\
1782.47 * * *\end{array}$ & $\mathrm{~F}(1,9)=13.873 * * *$ & $35.022 * * *$ & chi2(45)=82.268*** \\
\hline
\end{tabular}

Notes: $* * *$ denotes statistically significant at $1 \%$ level; $\mathrm{H}_{0}$ of Modified Wald test: sigma(i $)^{\wedge} 2=\operatorname{sigma}{ }^{\wedge} 2$ for all $\mathrm{i}$; $\mathrm{H}_{0}$ of Wooldridge test: no first-order autocorrelation; $\mathrm{H}_{0}$ of Friedman's test: residuals are not correlated.

The results from the specification tests suggest the rejection at $1 \%$ levels, in all null hypotheses of tests, cited more above, which means that heteroscedasticity, first-order autocorrelation, contemporaneous correlation, and non-presence of cross-sectional independence.

Indeed, in the presence of heteroscedasticity, first-order autocorrelation, contemporaneous correlation, and no presence of cross-sectional independence in the model, it is recommended the use of estimator Driscoll and Kraay (1998). The FE-D. K. (Driscoll and Kraay) was selected as the chief estimator to the realisation our analysis. To achieve the long-run elasticities, the coefficients of the variables divided by the LnIREC coefficient, both lagged once, and multiply this ratio by $(-1)$.

The dummy variables were added in the estimators, because of the presence of several shocks that affected the Latin America countries during the period of under analysis. For example, in 1981, Ecuador joint to brief territorial conflict dispute with Peru (Villamar, 1981). In this same year, the economy of Ecuador suffered from a financial crisis caused by international oil prices decline (Hanratty, 1989). In 1982 the economy of Ecuador was affected again by El Niño, which 
impacted the agriculture production negatively and also infrastructures and transportation (Hanratty, 1989).

Moreover, in 1983, Uruguay was impacted by payments crisis the began in 1982, where the external financing became more restrictive. In the same year, the peso was devalued by $149 \%$ against the US dollar, and the annual inflation climbed from 20.5\% in 1982 up to 51.5\% in 1983. The large stock of dollar-denominated debt of the private sector quickly caused severe solvency problems, which triggered a banking crisis (Oddone and Marandino, 2018). However, between 2004-2014 was considered the golden years for Uruguay economy, where in this period the annual growth rate of GDP was 5.4\%, three times the growth in the second half of the twentieth century. Indeed, this growth as caused by a super cycle of commodity prices, right financial conditions in emerging markets, and by strong external demand, especially after the 2008 international financial crisis (Oddone and Marandino, 2018). Therefore, in 2006, the annual growth rate of GDP was $4.09 \%$; in 2007, it was 6.54\%; finally, in 2008, it was 7.17\% (WDB, 2019).

The variables dummies added in the estimators were, for example: IDECUADOR1981 (Ecuador, year 1981); IDECUADOR1982 (Ecuador, year 1982); IDURUGUAY1983 (Uruguay, year 1983); IDURUGUAY2006 (Uruguay, year 2006); IDURUGUAY2007 (Uruguay, year 2007); and IDURUGUAY2008 (Uruguay, year 2008). However, these variable dummies followed the following criteria to be included in the estimators, such as (a) the presence of international events which were known to have affected the region; (b) the potential relevance of recorded social, political, and economic events that occurred in the region; and (c) significant disturbances in the estimated residuals. Table 6 shows the results, i.e., the short-run (impacts), long-run (elasticities), and the ECM, from the FE, FE Robust, and FE D.-K. estimators, with the inclusion of the dummy variables.

Table 6. Model's estimation

\begin{tabular}{|c|c|c|c|c|}
\hline \multirow{2}{*}{ Independent variables } & \multicolumn{4}{|c|}{ Dependent variable (DLnIREC) } \\
\hline & \multicolumn{2}{|c|}{ FE } & FE Robust & FE D.-K. \\
\hline Constant & \multicolumn{2}{|c|}{-0.0141} & & \\
\hline \multicolumn{5}{|c|}{ Shocks } \\
\hline IDECUADOR1981 & -0.7130 & $* * *$ & $* * *$ & $* * *$ \\
\hline IDECUADOR 1982 & -0.4922 & $* * *$ & $* * *$ & $* * *$ \\
\hline IDURUGUAY1983 & 0.9077 & $* * *$ & $* * *$ & $* * *$ \\
\hline IDURUGUAY2006 & -0.6976 & $* * *$ & $* * *$ & $* * *$ \\
\hline IDURUGUAY2007 & 0.4941 & $* * *$ & $* * *$ & $* * *$ \\
\hline IDURUGUAY2008 & -0.4659 & $* * *$ & $* * *$ & $* * *$ \\
\hline \multicolumn{5}{|c|}{ Short-run (impacts) } \\
\hline DLnGDP & 0.4540 & $* *$ & $* *$ & $* *$ \\
\hline \multicolumn{5}{|c|}{ Long-run (elasticities) } \\
\hline $\operatorname{LnGLOBA}(-1)$ & 1.3400 & $* * *$ & $* * *$ & $* * *$ \\
\hline $\operatorname{LnKPRIV}(-1)$ & 0.2322 & $* *$ & $* *$ & $*$ \\
\hline \multicolumn{5}{|c|}{ Speed of adjustment } \\
\hline $\mathrm{ECM}$ & -0.3547 & $* * *$ & $* * *$ & $* * *$ \\
\hline
\end{tabular}

Notes: $* * *, * *$ denote statistically significant at $1 \%, 5 \%$ and $10 \%$ level, respectively; The ECM denotes the coefficient of the variable LnIREC, lagged once; (Ln and DLn) denote variables in natural logarithms and firstdifferences of logarithms respectively.

The results from Table 6, points that in the semi-elasticity of GDP per capita increases the installed capacity of renewable energy. The effect of this variable is statistically significant at $5 \%$ levels. Moreover, the elasticities of variables, GLOBA and KPRIV per capita contribute to increasing of installed capacity. The impact of these variables is statistically significant at $1 \%$ levels. The ECM term is negative and statistically significant at $1 \%$ levels, which points to the presence of long memory in the variables. The next section will present a more profound discussion of the results from the model estimations. 


\section{Discussion}

The impact of globalisation on renewable energy diffusion in a group of ten Latin America countries was studied. The preliminary tests point to the existence of low multicollinearity (see Table 2); cross-sectional dependence (see Table 2). Moreover, the CSD-test indicate the presence of cross-sectional dependence in the variables in logarithms and first-differences in almost all cases, except the variable IREC in the first differences. Although the non-presence of CSD in the variable IREC in the first differences, one can conclude for the presence of correlation between the series across countries. This result is due to the interdependency that exists across the economies from the countries in our sample; The stationarity in all variables in the firstdifferences and also IREC and GLOBA in the natural logarithms (see Table 3). Moreover, the variables in first-differences and some in the natural logarithms such as IREC and GLOBA seem to be stationary. The results of CIPS-test confirm that the best approach is the PARDL methodology in the form of UECM because it allows the inclusion of variables with different integration orders in the same estimation; the presence of fixed effects in the model; and finally that the model is homogeneous and that the FE is the most appropriate estimator (see Table 4).

The results of specification tests indicate the presence of heteroscedasticity, first-order autocorrelation, contemporaneous correlation, and non-presence of cross-sectional independence (see Table 5). In the presence of heteroscedasticity, first-order autocorrelation, contemporaneous correlation, and non-presence of cross-sectional independence, it is necessary to use the Driscoll and Kraay (1998) estimator that produces standard errors robust to the phenomena that were found in the sample errors better than FE and FE robust. For this reason, FE-D. K. (Driscoll and Kraay) was chosen as the only estimator of this study.

The results of PARDL estimation indicate that in the short-run impact of GDP per capita increases 0.4540 the installed capacity of renewable energy (see Table 6). The possible explanation for the positive effect of economic growth on the installed capacity of renewable energy is the change in the economic activity in the Latin America countries. The faster economic growth of these countries exerts a positive effect on the consumption of energy, and consequently to meet this growth in the consumption, the investments in installed capacity, it is done (Koengkan, 2017a). There is another explanation for this phenomenon, where according to Koengkan (2017b) the enormous abundance of renewable energy resources in the Latin America countries, stimulate the investments of alternative energy sources, that consequently exerts a positive effect on economic activity and consumption of energy.

Moreover, the elasticities of variables, GLOBA and KPRIV per capita contribute to increasing of 1.3400 and 0.2322 , respectively (see Table 6). Indeed, the positive impact of private capital stock is due to the capital abundance makes the capital cheaper which, consequently, affect the economic activity and the energy consumption positively, and also the investments in installed capacity of energy (e.g. Lee and Chien, 2010; Lee et al., 2008). Additionally, there are other explanations for this positive impact. Lee (2005) affirms that the private/public capital stock has an indirect effect on consumption and investments of energy. Lee and Chien (2010) have the same point of view, however, following the authors the capital stock has a positive impact on investment and industrial production which in consequence, leads to an increase in the energy demand and the investments in installed capacity. Nevertheless, Apergis and Payne (2010) and Narayan and Smyth (2008), have a different opinion about this positive impact. On the word of these authors, the private/public capital stock, encourages the investments of renewable energy sources, due to the cheap credit, which makes the renewable energy sources more feasible than non-renewable sources.

Finally, there are some explanations given by some authors about the positive effect of globalisation on the installed capacity of energy. According to Koengkan (2017c), the 
globalisation process exerts a positive impact on economic growth and consequently increase the energy demand, and the new investments in renewable technologies in order to meet the demand. Leitão (2014) confirms that the trade liberalisation and the international rules of environmental encourage the economies to use renewable energy sources. Moreover, another possible explanation for this positive impact is that the globalisation encourages investments in renewable sources. These new investments exert a positive impact on economic growth and subsequently in energy consumption. Moreover, the globalisation can allow households and firms to purchase renewable energy technology more cheaply, increasing the consumption of green energy. Based on these recent literature accounts, we can summarise the impact of globalisation on the installed capacity of renewable energy, as shown in Fig. 1.

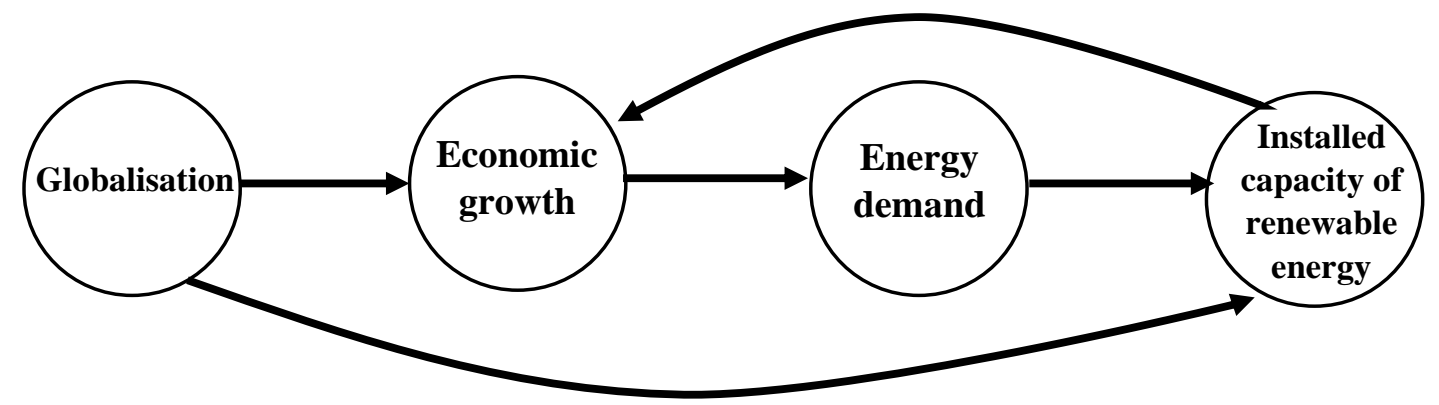

Fig. 1 Summary of the impact of globalisation on the installed capacity of renewable energy

The ECM term is negative and statistically significant at $1 \%$ levels, which points at least to the presence of long memory in the variables. Moreover, this coefficient value evidence also that the speed of adjustment is relatively moderate and that our dependent variable returns to equilibrium. Moreover, the statistical significance of the dummy variables that were included in the model seems to point for the fact that their inclusion is a good practice.

\section{Conclusions and policy implications}

This study focused on investigating the influence of globalisation on renewable energy diffusion with the utilisation of the installed capacity of renewable energy as a dependent variable. Indeed, ten countries from the Latin America region were selected, and a period from 1980 to 2014 showed to be the most appropriate one. Moreover, this investigation opted to use as the methodology the PARDL in the form of a UECM.

The preliminary tests of this investigation pointed that the variables used have following characteristics, such as low-multicollinearity, cross-sectional dependence in the variables in logarithms and first-differences in almost all cases, $\mathrm{I}(0) / \mathrm{I}(1)$ for all variables, and the presence of fixed effects. Moreover, the specification tests indicated the presence of heteroscedasticity, firstorder autocorrelation, contemporaneous correlation, and also the non-presence of cross-sectional independence. Therefore, the results of these tests are essential in order to identify the characteristics of countries that are study as well as possible methodologies will be applied.

Indeed, the results of the model's estimation indicated that the short-run impact of variable GDP per capita has a positive effect on renewable energy diffusion (installed capacity of renewable energy), while the elasticities of variables globalisation and private capital stock per capita exert the same effect. Moreover, the results that show that the globalisation can stimulate renewable energy sources, it is evidence that the process of integration of Latin America countries with the rest of world is a benefit to the development of green energy technologies. This because 
it includes this group of countries in the race against climate change, green development, and in renewable energy technology development.

It is noteworthy that the governments from the Latin America region have to take advantage in this process of integration with other nations and develop even more renewable energy technologies with their geographical and climate characteristics. Then, the technological transfer makes it easier with this process of integration, where enables that these countries adopt adequate renewable energy technologies. Moreover, the countries from the Latin American region could adopt the successful renewables policies of similar countries, as well as economic incentives that would accelerate the diffusion of renewables energies, even when they are not in their maturity stage. The Latin America countries should have an increase in renewable energy production to meet their energy's needs without falling to non-renewable ones, and consequently letting them reduces their $\mathrm{CO}_{2}$ emissions.

The policymakers must take advantage of the process of globalisation Trade integration reduces the costs of renewable energy technology. The development of policies that encourage the access of these technologies by households with low income and that live in remote or rural regions should be incentivised to reduce the energy poverty, which plagues the countries from the Latin America region. Additionally, policymakers must implement more strict environmental regulations to reduce the effect of the "free-rider" phenomenon on $\mathrm{CO}_{2}$ emissions. The globalisation could induce environmental policies that can be harmful to the environment, where the pollution industry from heavily regulated developed countries can move to develop countries with less demanding environmental regulation. Indeed, a weak environmental regulation is the situation in the Latin American region. This phenomenon is worrisome in the case of global pollutants, where the globalisation process can hamper the efforts to reduce $\mathrm{CO}_{2}$ emissions.

This investigation has a significant contribution to the literature for several reasons. First, shed light on how the process of globalisation affects the investments on renewable energy. Indeed, this understanding can contribute to promoting economic policies that encourage the development of renewable energy in developing countries. Second, the results of this investigation have critical consequences to the local governments appraise of the relationship between the globalisation process and renewable energy investments. Indeed it incentivises the policymakers of the most protectionist countries to rethink their trade and economic policy. Finally, this investigation will help policymakers to develop appropriate energy policies aiming to reduce fossil fuels and boost investments, development, and consumption of renewable sources to mitigate the environmental degradation and tool better economic policies for Latin American countries.

\section{References}

Apergis N., Payne J.E., (2010). Renewable energy consumption and economic growth: Evidence from a panel of OECD countries. Energy Policy, 38(1):656-660. doi: https://doi.org/10.1016/j.enpol.2009.09.002.

Breusch T.S, Pagan A.R., (1980). The Lagrange multiplier test and its applications to model specification in econometrics. The Review of Economic Studies, 47(1):239-253.

Driscoll J. C., Kraay, A. C., (1998). Consistent Covariance Matrix Estimation with Spatially Dependent Panel Data. Review of Economics and Statistics, 80(4):549-560. https://doi.org/10.1162/003465398557825.

Engle R., Granger G., (1987). Cointegration and Error Correction: Representation, Estimation and Testing, Econometrica, 55:251-276.

Friedman M., (1937). The use of ranks to avoid the assumption of normality implicit in the analysis of variance', Journal of the American Statistical Association, 32:675-701. 
Fuinhas J.A., Marques A.C., Koengkan M., (2017). Are renewable energy policies upsetting carbon dioxide emissions? The case of Latin America countries. Environmental Science and Pollution Research, 24(17):15044-15054. doi: https://link.springer.com/article/10.1007/s11356-017-9109-z.

Gielen, D., Boshell, F., Saygin, D., Bazilian, D., Wagner, N., Gorini, R., (2019). The role of renewable energy in the global energy transformation. Energy Strategy Reviews, 24:38-50.

Granger C.W.J., (1981). Some Properties of Time Series Data and Their Use in Econometric Model Specification, Journal of Econometrics, 28:121-130.

Greene W., (2002). Econometric Analysis. Upper Saddle River, New Jersey: Prentice-Hall.

Griffith-Jones, S., Spratt, S., Andrade, R., Griffith-Jones, E., (2017). Investment in renewable energy, fossil fuel prices and policy implications for Latin America and the Caribbean. Santiago: Economic Commission for Latin America and the Caribbean.

Hanratty D.M., (1989). Ecuador: a country study. Washington, D.C.: Federal Research Division, Library of Congress, p. 1-341. https://lccn.loc.gov/91009494.

Horbach J., \& Rammer, C., (2018). Energy transition in Germany and regional spill-overs: The diffusion of renewable energy in firms. Energy Policy, 121:404-414.

IMF, Investiments and Capital Stock, (2017). Available in https://www.imf.org/external/np/fad/publicinvestment/data/data122216.xlsx.

International Energy Agency (IEA), (2018). Available in: https://www.iea.org/energyaccess/database/.

Johansen J., Juselius K., (1990). Maximum Likelihood Estimation and Inference on Cointegration-with Applications to the Demand for Money. Oxford Bulletin of Economics and Statistics, 52(2):169-210.

Jones T., (1998). Economic Globalisation and the environment: an overview of the linkages. OECD, Globalisation and the Environment: Perspectives from OECD and Non-Member Economies. Paris.

Koengkan M., Fuinhas J.A., Marques A.C., (2019a). The role of financial openness and China 's income on fossil fuels consumption: fresh evidence from Latin American countries. GeoJournal, p. 1-15. doi: https://doi.org/10.1007/s10708-019-09969-1.

Koengkan M., Santiago R., Fuinhas J.A., Marques A.C., (2019b). Does financial openness cause the intensification of environmental degradation? New evidence from Latin American and Caribbean countries. Environmental Economics and Policy Studies, p. 1-26.doi: https://doi.org/10.1007/s10018-019-00240-y.

Koengkan M., (2018a). The decline of environmental degradation by renewable energy consumption in the MERCOSUR countries: an approach with ARDL modelling. Environment Systems and Decisions, 38(3):415-425. doi: https://doi.org/10.1007/s10669018-9671-z.

Koengkan M., (2018b). The positive impact of trade openness on consumption of energy: Fresh evidence from Andean community countries. Energy, 158, p.936-943. doi: https://doi.org/10.1016/j.energy.2018.06.091.

Koengkan M., (2017a). The nexus between energy consumption, economic growth, and urbanization in Latin American and Caribbean countries: An approach with the PVAR model. Revista Valore, 6(2):202-218. doi:10.22408/reva22201761\%25p.

Koengkan M., (2017b). The nexus between consumption of biofuels and economic growth: An empirical evidence from Brazil. Cadernos UniFOA, Volta Redonda, 12(35):87-98. ISSN: 1809-9475. 
Koengkan M., (2017c). Is the globalization influencing the primary energy consumption? The case of Latin America and the Caribbean countries. Cadernos UniFOA, Volta Redonda, 12(33):59-69. ISSN:1809-9475.

KOF Globalization index, (2018). Available in: https://www.kof.ethz.ch/en/forecasts-andindicators/indicators/kof-globalisation-index.html.

Lacal-Arántegui, R., (2019). Globalization in the wind energy industry: contribution and economic impact of European companies Roberto Lacal-Arantegui. Renewable Energy, 134:612-628.

Lee C-C., (2005). Energy consumption and GDP in developing countries: A cointegrated panel analysis. Energy Economics, 27(3):415-427. doi: https://doi.org/10.1016/j.eneco.2005.03.003.

Lee C-C., Chang C-P., Chen P-F., (2008). Energy-income causality in OECD countries revisited: The key role of capital stock. Energy Economics, 30(5):2359-2373. doi: https://doi.org/10.1016/j.eneco.2008.01.005.

Lee C-C., Chen P-F., (2010). Dynamic modelling of energy consumption, capital stock, and real income in G-7 countries. Energy Economics, 32(3):564-581. doi: https://doi.org/10.1016/j.eneco.2009.08.022.

Leitão N.C., (2014). Economic Growth, Carbon Dioxide Emissions, Renewable Energy and Globalization. International Journal of Energy Economics and Policy, 4(3):391-399. ISSN: 2146-4553.

Narayan P.K., Smyth R., (2008). Energy consumption and real GDP in G7 countries: New evidence from panel cointegration with structural breaks. Energy Economics, 30(5):23312341. doi: https://doi.org/10.1016/j.eneco.2007.10.006.

Oddone G.,Marandino J., (2018). The Monetary and Fiscal History of Uruguay 1960-2017. Becker Friedman Institute: For economics at the University of Chicago, working paper $n^{\circ}$ 60, p. 1-34. https://bfi.uchicago.edu/sites/default/files/file_uploads/WP_2018-60.pdf.

Overland I., (2015). Future Petroleum Geopolitics: Consequences of Climate Policy and Unconventional Oil and Gas. Em L. John Wiley \& Sons, Handbook of Clean Energy Systems (p. 1-29). NJ, USA.

Overland I., (2016). Energy: The missing link in globalization. Energy Research \& Social Science, 14:122-130.

Pesaran M. H., Smith R., (1995). Estimating long-run relationships from dynamic heterogeneous panels. Journal of Econometrics, 68(1):79-113. https://doi.org/10.1016/03044076(94)01644-F.

Pesaran M.H., Shin Y., Smith R.P., (1999). Pooled mean group estimation of dynamic heterogeneous panels. Journal of American Statistical Association, 94(446):621-634. URL: http://www.jstor.org/stable/2670182.

Pesaran M.H., (2004). General diagnostic tests for cross section dependence in panels. The University of Cambridge, Faculty of Economics. Cambridge Working Papers in Economics, n. 0435.

Pesaran M.H., (2007). A simple panel unit root test in the presence of cross-section dependence. Journal of Applied Econometrics, 22(2):256-312. doi:10.1002/jae.951.

Storper M., (2000). Globalization and Knowledge Flows And industrial geographer's perspective. Oxford University Press, Oxford. (J. Dunning, Ed.).

United Nations, (2018). World Investment Report 2018: Investment and New Industrial Policies. Geneva: United Nations Publication.

Villamar C.M., (1981). Paquisha: toda la verdade. Letra Nueva, Quito. 
Washburn C., Pablo-Romero, M., (2019). Measures to promote renewable energies for electricity generation in Latin American countries. Energy Policy, 128:212-222.

Wooldridge J.M., (2002). Econometric analysis of cross section and panel data. The MIT Press Cambridge, Massachusetts London, England.

World Bank Data., (2019). Available in http://www.worldbank.org/.

World Trade Organisation, (2019). World Trade Organisation. Fonte: World Trade Statistical Review 2018: https://www.wto.org/english/res_e/statis_e/wts2018_e/wts18_toc_e.htm. Accessed February $1^{\text {st }} 2019$. 